\title{
Analisa uji ketahanan fatigue Aluminium scrap hasil remelting sepatu rem (brake shoe) terhadap variasi beban menggunakan tipe rotary bending
}

\author{
Wahyono' $^{1}$ Eko Nugroho², Sulis Dri Handono ${ }^{3}$, Eko Budiyanto ${ }^{4}$ \\ Jurusan Teknik Mesin, Fakultas Teknik, Universitas Muhammadiyah Metro 1,2,3,4 \\ JI. Ki Hajar Dewantara 15 A Kota Metro, Lampung, Indonesia \\ "Coresponding author: eko_budiyanto99@yahoo.com
}

\begin{abstract}
Used brake shoes are a component of a two-wheeled vehicle that has a type of aluminum material. Therefore, we can do remelting aluminum from brake shoes that can no longer be used for advanced application use and utilization of brake shoe waste which still has a sale value. This study aims to determine the best value or the one that approximates the fatigue limit endurance value of each loading variation given to the specimen and to determine the characteristics of the fracture surface from the differences in given loading. The research method used for fatigue testing is by using a literature study and direct observation or observation. Before doing the fatigue testing, first, do the tensile test to get the yield strength value where this value is used for the loading that will be given to the fatigue test, the loading variations are given for the fatigue test are $40 \%, 50 \%$, and $60 \%$ of the yield strength value. From the results of fatigue testing at a load of 60\% with the stress of 100.2 $\mathrm{MPa}$ and a given load of $3.81 \mathrm{~kg}$, it can be seen that the value of material fracture at 27,421 cycles and in the timeframe 00:18:16. Then at 50\% loading with the stress of $83.5 \mathrm{MPa}$ and a given load of $3.18 \mathrm{~g}$, it can be seen that the fracture value of the material in the 51,659 cycles in the fracture period is 00:34:35. Then in the next test with a load of 40\% and given the stress of $66.8 \mathrm{MPa}$ and a load of $2.5 \mathrm{~kg}$, it is known that the fracture value of the material in the 106,930 cycles in the fracture period reaches 01:11:17. From the test data, it can be concluded that the ratio between cycle and time with voltage is inversely proportional, that is, the smaller the voltage the greater the cycle and time obtained, and vice versa, the greater the voltage, the smaller the cycle and time will be obtained.
\end{abstract}

Keywords: Used brake shoes, Aluminum, Remelting, load variation, fatigue test.

\begin{abstract}
Abstrak
Sepatu rem bekas adalah suatu komponen kendaraan roda dua yang memiliki jenis material aluminium. Maka dari itu aluminium dari sepatu rem yang sudah tidak dapat lagi di gunakan bisa kita lakukan remelting atau peleburan ulang untuk penggunaan aplikasi lanjutan dan pemanfaatan limbah sepatu rem yang masih mempunyai nilai jual. Tujuan penelitian ini adalah untuk mengetahui nilai terbaik atau yang mendekati nilai endurance limit kelelahan dari setiap variasi pembebanan yang di berikan terhadap spesimen dan untuk mengetahui karakteristik permukaan patahan dari perbedaan pembebanan yang di berikan. Metode penelitian yang di gunakan untuk pengujian fatigue ini dengan menggunakan studi pustaka dan pengamatan secara langsung atau obserasi. Sebelum di lakukan pengujian fatigue, terlebih dahulu di lakukan pengujian tarik untuk mendapatkan nilai yield strengh di mana nilai ini di gunakan untuk pembebanan yang akan di berikan terhadap pengujian fatigue, variasi pemebebanan yang di berikan untuk pengujian fatigue yaitu $40 \%, 50 \%$, dan $60 \%$ dari nilai yield strengh. Dari hasil pengujian fatigue pada pembebanan $60 \%$ dengan tegangan 100,2 MPa dan beban yang di berikan 3,81 kg dapat diketahui nilai patah material pada siklus
\end{abstract}


27.421 dan dalam kurun waktu 00:18:16. Kemudian pada pembebanan $50 \%$ dengan tegangan 83,5 MPa dan beban yang di berikan 3,18 g dapat di ketahui nilai patah material pada siklus 51.659 dalam kurun waktu patah 00:34:35. Lalu pada pengujian yang berikutnya dengan pembebanan $40 \%$ serta tegangan yang di berikan $66,8 \mathrm{MPa}$ dan beban yang di berikan $2,5 \mathrm{~kg}$ di ketahui nilai patah materialnya pada siklus 106.930 dalam jangka waktu patah mencapai 01:11:17. Dari data pengujian dapat di simpulkan bahwa perbandingan antara siklus dan waktu dengan tegangan adalah berbanding terbalik, yaitu semakin kecil tegangan semakin besar siklus dan waktu yang di dapat, begitupun sebaliknya semakin besar tegangan maka akan semakin kecil siklus dan waktu yang didapat.

Kata kunci : Sepatu rem bekas, Aluminium, Remelting, Variasi beban, Uji fatigue.

\section{Pendahuluan}

Perkembangan ilmu pengetahuan dan kemajuan teknologi yang semakin pesat di era globalisasi membuat kebutuhan akan penggunaan matrial logam semakin meningkat. Diantaranya logam aluminium sebagai salah satu komponen pada kendaraan bermotor dan biasanya di gunakan untuk bahan baku pembuatan sepatu rem (brake shoe). Akan tetapi penggunaan sepatu rem tersebut menimbulkan limbah yang cukup banyak dan masih mempunyai nilai jual. Karena alumunium masih bisa di daur ulang dan di manfaatkan menjadi produk yang mempunyai nilai jual, maka dari itu pengolahan daur ulang aluminium bekas sepatu rem ini sangat penting dilakukan.

Salah satu aplikasi aluminium adalah sebagai bahan baku pembuatan sepatu rem yang menjadi tumpuan kanvas rem agar mampu mengurangi dan menghentikan laju kendaraan. Sepatu rem ini memiliki paduan antara Alumunium (Al) dan Silikon (Si), dimana kandungan Silikon yang di campurkan sebagai bahan baku sepatu rem hanya $12 \%$,

Sehingga setelah kanvas rem ini habis biasanya sepatu rem tersebut tidak lagi dapat di gunakan, maka dari itu sepatu rem yang sudah tidak dapat lagi di gunakan bisa kita lakukan remelting untuk penggunaan aplikasi lanjutan dan pemanfaatan limbah sepatu rem tersebut, akan tetapi hal ini perlu di lakukan pengujian mekanik yang salah satunya ialah uji ketahanan fatique, dari pengujian ini akan dihasilkan kurva atau data yang mencirikan keadaan dari material tersebut., dan menurut jurnal yang saya baca perlakuan remelting ini berpengaruh terhadap ketahanan dan kekuatan suatu matrial. Jika suatu matrial di beri perlakuan remelting maka ketahanan dan kekuatan material tersebut akan semakin berkurang [5].

\section{Tinjauan Pustaka}

\section{Aluminium}

Aluminium merupakan salah satu logam non ferrous yang paling banyak di pergunakan dalam bidang keteknikan karena memiliki sifat yang ringan dan tahan terhadap korosi. Terdapat banyak paduan dari aluminium diantaranya seperti Al-Si, $\mathrm{Al}-\mathrm{Cu}, \mathrm{Al}-\mathrm{Mg}$ dn Al-Zn serta banyak paduan-paduan aluminium lainnya. Masing -masing paduan ini mempunyai karaktaristik yang berbeda-beda dengan tujuan pemakaian yang berbeda pula.

Aluminium dipergunakan secara luas bukan saja untuk peralatan rumah tangga, tetapi juga dipakai untuk keperluan matrial pesawat terbang, otomotif, kapal laut, konstruksi dan lain-lain. Bahkan di dunia otomotif aluminium merupakan matrial yang menarik karena dapat menurunkan berat kendaraan dan penggunaan aluminium diharapkan dapat menekan kenaikan bahan bakar serta matrial ini juga mudah untuk didaur ulang (recyclabe). Hal ini yang mendorong penggantian bagian dari besi (ferrous) menjadi aluminium [6]. 
A. Sifat Fisis Aluminium

Aluminium memiliki struktur kristal face centred cubic (FCC) dengan kristal (a) $=4,0413 \mathrm{~A}$ pada temperatur $25^{\circ} \mathrm{C}(\mathrm{HORN}$, 1967). Aluminium merupakan logam ringan, dimana memiliki berat $34 \%$ dari besi dengan volume yang sama, $30 \%$ dengn volume yang sama di bandingkan dengan tembaga, akan tetapi memilik berat 1,5 kali di ban dingkan dengan magnesium. Aluminium mempunya ketahanan korosi yang baik dan mempunyai hantaran listrik yang baik serta sifat sifat lainya sebagai sifat logam.

Tabel 1. Sifat-sifat fisik Aluminium

\begin{tabular}{lcc}
\hline \multicolumn{1}{c}{ Sifat-sifat } & \multicolumn{2}{c}{ Kemurnian AL (\%) } \\
\cline { 2 - 3 } & $\mathbf{9 9 , 9 9 6}$ & $\mathbf{9 9 , 0}$ \\
\hline Massa Jenis $\left(20^{\circ} \mathrm{C}\right)$ & 2,6989 & 2,71 \\
\hline Titik Cair & 660,2 & $653-657$ \\
\hline $\begin{array}{l}\text { Panas Jenis } \\
\left(\text { cal }^{\circ} \mathrm{C}\right)\left(100^{\circ} \mathrm{C}\right)\end{array}$ & 0,2226 & 0,2297 \\
\hline $\begin{array}{l}\text { Hantaran Listrik } \\
(\%)\end{array}$ & 64,94 & 59 (dianil) \\
\hline $\begin{array}{l}\text { Tahanan Listrik } \\
\text { Koefisien } \\
\text { Temperatur }\left({ }^{\circ} \mathrm{C}\right)\end{array}$ & 0,00429 & 0,0115 \\
\hline $\begin{array}{l}\text { Koefisien } \\
\text { Pemuaian }(20- \\
100^{\circ} \mathrm{C}\end{array}$ & $23,86 \times 10-6$ & $23,5 \times 10-6$ \\
\hline $\begin{array}{l}\text { Jenis Kristal, } \\
\text { Konstanta kisi }\end{array}$ & FCC, a = 4,013 A & FCC, a = 4,04 A \\
\hline
\end{tabular}

\section{B. Sifat Mekanis Aluminium}

Perlu diketahui aluminium memiliki beberapa sifat yang menjadikannya sebagai salah satu bahan yang banyak dipergunakan dalam banyak aplikasi industri seperti industri otomotif, rumah tangga, maupun elektrik, karena beberapa sifat dari aluminium itu sendiri, yaitu:

1. Ringan

Aluminium meliki sifat ringan, bahkan lebih ringan dari magnesium dengan densitas sekitar 1/3 dari densitas besi. Kombinasi ringan dengan kekuatan yang cukup baik membuat aluminium sering diaplikasikan pada kendaraan bermotor, pesawat terbang, alat-alat rumah tangga, maupun pada roket.

2. Mudah dalam pembentukannya

Aluminium merupakan salah satu logam yang mudah untuk dibentuk dan mudah dalam fabrikasi seperti forging, bending, rolling, casting, drawing, dan machining. bahan aluminium juga mudah dibentuk menjadi bentuk yang komplek dan tipis sekalipun, seperti bingkai jendela, lembaran aluminium foil, rel, gording, dan lain sebagainya.

3. Tahan terhadap korosi

Aluminium tahan terhadap korosi karena fenomena pasivasi. Pasivasi adalah pembentukan lapisan pelindung akibat reaksi logam terhadap komponen udara sehingga lapisan tersebut melindungi lapisan dalam logam dari korosi. Hal tersebut dapat terjadi karena permukaan aluminium mampu membentuk lapisan aluminium $\left(\mathrm{Al}_{2} \mathrm{O}_{3}\right)$ bila bereaksi dengan oksigen.

4. Konduktivitas panas tinggi

Konduktivitas panas aluminium tiga kali lebih besar dari besi, maupun dalam pendinginan dan pemanasan. Sehingga aplikasi banyak digunakan pada radiator mobil, koil pada evaporator, alat penukar kalor, alat-alat masak, maupun komponen mesin.

5. Konduktifitas listrik tinggi

Konduktifitas listrik dari aluminium dua kali lebih besar dari pada tembaga dengan perbandingan berat yang sama. Sehingga sangat cocok digunakan dalam kabel transmisi listrik.

6. Tangguh pada temperatur rendah

Aluminium tidak menjadi getas pada temperatur rendah hingga $-100{ }^{\circ} \mathrm{C}$, bahkan menjadi lebih keras dan ketangguhan meningkat. Sehingga aluminium dapat digunakan pada matrial bejana yang beroperasi pada temperatur rendah.

7. Tidak beracun

Aluminium tidak memiliki sifat racun pada tubuh manusia, sehingga sering digunakan dalam industri makanan seperti kaleng makanan dan minuman, serta pipapipa penyalur pada industri makanan dan minuman.

8. Mudah didaur ulang

Aluminium mudah untuk didaur ulang, bahkan $30 \%$ produksi aluminium di amerika berasal dari aluminium yang 
didaur ulang. Pembentukan kembali aluminium dari matrial bekas hanya membutuhkan 5\% energi dari pemisahan aluminium dan bauksit.

\section{Sepatu rem (brake shoe)}

Rem adalah suatu peranti untuk memperlambat atau menghentikan gerakan roda. Karena gerak roda diperlambat, secara otomatis gerak kendaraan menjadi lambat. Dalam sistem pengereman sepatu rem berfungsi sebagai tempat melekatnya kampas rem. Sepatu rem memiliki peran yang sangat penting dalam sistem pengereman, yaitu menghubungkan antara komponen master rem yang berhubungan dengan tuas rem yang digerakkan oleh pengendara dengan kampas rem yang akan bergesekan langsung dengan tromol untuk menghentikan laju kendaraan [2].

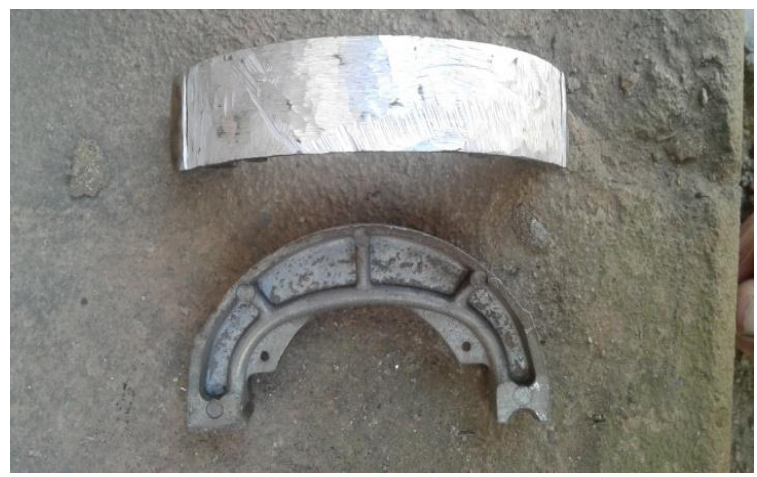

Gambar 1. Sepatu rem

Apabila dibandingkan dengan lining (kampas) pada bagian rem, sepatu rem adalah bagian yang jarang mengalami kegagalan. ADC 12 paduan aluminium dan Silikon $12 \%$ digunakan sebagai bahan untuk membuat sepatu rem. ADC 12 memiliki keunggulan sebagai berikut :

1. Memiliki berat yang relatif ringan.

2. Tahan terhadap korosi.

3. konduktivitas termal tinggi.

4. Lunak tapi kuat sehingga apabila kampas rem habis, sepatu rem tidak rusak.

5. Ulet sehingga jarang ditemuan retakan .

\section{Remelting}

Remelting merupakan salah satu metode yang dapat digunakan untuk memperoleh suatu material dengan sifat fisik dan sifat mekanik yang diinginkan dengan merubah sifat yang dimiliki bahan dasarnya. Pada dasarnya proses remelting merupakan proses peleburan dan penuangan kembali material yang sebelumnya sudah mengalami peleburan. Remelting juga merupakan bagian dari siklus hidup aluminium.

\section{Suhu Tuang}

Suhu penuangan dalam proses pengecoran merupakan salah satu hal yang sangat berpengaruh penting, karena akan sangat berpengaruh dalam hasil cetakan. Suhu tuang aluminium yang terlalu rendah maka rongga cetakan tidak akan terisi penuh dimana saluran masuk akan terbuka terlebih dahulu, dan apabila suhu tuang terlalu tinggi maka hal ini akan mengakibatkan penyusutan dan kehilangan akan keakuratan dimensi coran. Suhu tuang pada aluminium biasanya terdapat pada range $675-790^{\circ} \mathrm{c}$ dan harus tetap diperhatikan pada saat penuangan. Suhu tuang pada saat pengecoran sangat penting untuk diperhatikan karena faktor ini akan sangat mempengaruhi kualitas coran yang meliputi mikrostruktur dan sifat mekanis.

\section{Uji Tarik}

Pengujian tarik yaitu pengujian yang bertujuan untuk mendapatkan gambaran tentang sifat-sifat dan keadaan dari suatu logam. Pengujian tarik dilakukan dengan penambahan beban secara perlahan-lahan, kemudian akan terjadi pertambahan panjang yang sebanding dengan gaya yang bekerja. Kesebandingan ini terus berlanjut sampai bahan sampai titik propotionality limit. Setelah itu pertambahan panjang yang terjadi sebagai akibat penambahan beban tidak lagi berbanding lurus, pertambahan beban yang sama akan menghasilkan penambahan panjang yang lebih besar dan suatu saat terjadi penambahan panjang 
tanpa ada penambahan beban, batang uji bertambah panjang dengan sendirinya. Hal ini dikatakan batang uji mengalami yield (luluh). Keadaan ini hanya berlangsung sesaat dan setelah itu akan naik lagi.
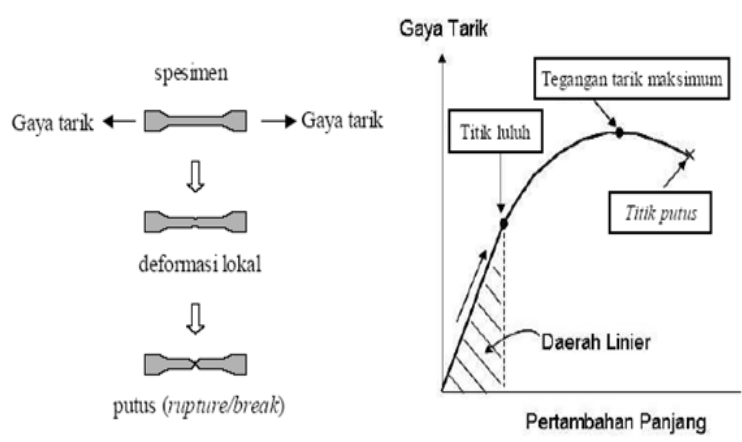

Gambar 2. Diagram Tegangan-Regangan

\section{Uji Fatik (Fatigue)}

Fatigue atau kelelahan didefinisikan sebagai proses perubahan struktur permanen progressive localized pada kondisi yang menghasilkan fluktuasi regangan dan tegangan dibawah kekuatan tariknya dan pada satu titik atau banyak titik yang dapat memuncak menjadi retak (crack) atau patahan (fracture) secara keseluruhan sesudah fluktuasi tertentu [9].

Progressive mengandung pengertian proses fatigue terjadi selama jangka waktu tertentu atau selama pemakaian, sejak komponen atau struktur digunakan. Localized berarti proses fatigue beroperasi pada luasan lokal yang mempunyai tegangan dan regangan yang tinggi karena : pengaruh beban luar, perubahan geometri, perbedaan temperatur, tegangan sisa dan tidak kesempurnaan diri. Crack merupakan awal terjadinya kegagalan fatique dimana kemudian crack merambat karena adanya beban berulang. Fracture merupakan tahap akhir dari proses fatigue dimana bahan tidak dapat menahan tegangan dan regangan yang ada sehingga patah menjadi dua bagian atau lebih.

Penyajian data fatique rekayasa adalah menggunakan kurva S-N yaitu pemetaan tegangan (S) terhadap jumlah siklus sampai terjadi kegagalan (N). Kurva $\mathrm{S}-\mathrm{N}$ ini lebih diutamakan menggunakan skala semi log seperti ditunjukan pada gambar 3. Untuk beberapa bahan teknis yang penting [13].

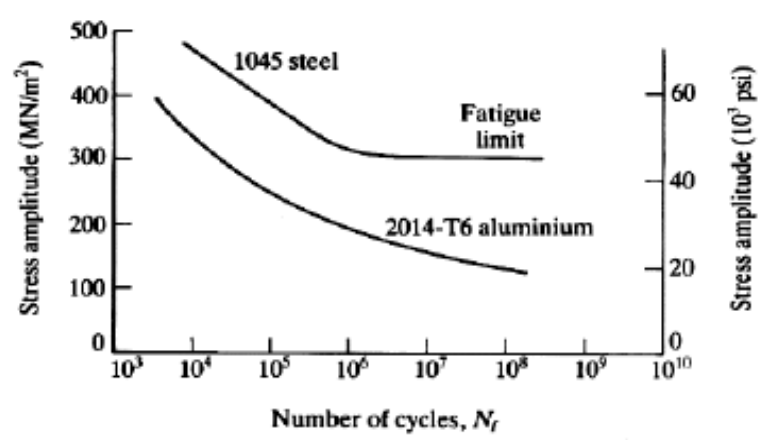

Gambar 3. Kurva S-N

Perhitungan beban yang di berikan pada uji fatigue menggunakan rumus:

$$
\begin{aligned}
& \sigma=\frac{W L / 2}{\pi / 32 d^{3}} \mathrm{~kg} / \mathrm{cm}^{2} \text {. di mana: } \\
& \sigma \quad=\text { Tegangan lentur }\left(\mathrm{kg} / \mathrm{cm}^{2}\right) \\
& \mathrm{W}=\text { Beban lentur }(\mathrm{kg}) \\
& \mathrm{D}=\text { Diameter benda uji }(\mathrm{mm}) \\
& \mathrm{L}=\text { = Panjang benda uji }(\mathrm{mm})
\end{aligned}
$$

\section{Metode Penelitian}

\section{Spesimen benda uji}

Benda uji untuk pengujian ketahanan fatigue berdasarkan standar ASTM E8 mempunyai ukuran dan bentuk di tunjukan pada gambar 10 berikut ini:

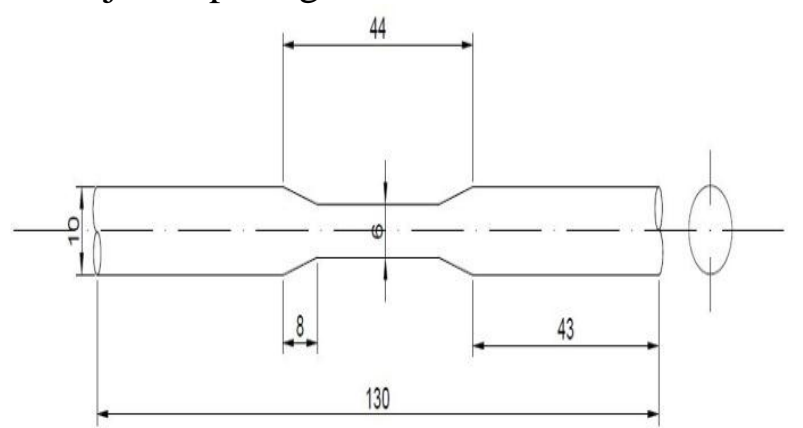

Gambar 4. Spesimen uji fatigue standar ASTM E8

\section{Prosedur penelitian}

Metode ini dilakukan dengan melakukan penyiapan bahan yang diperlukan untuk proses penelitian. Proses peleburan dilakukan dengan cara memasukkan aluminium kedalam tungku 
peleburan dengan menggunakan cangkang karet sebagai bahan bakarnya.

Setelah melakukan proses peleburan, aluminium yang telah mencair dituangkan dalam cetakan yang terbuat dari logam. Untuk mempermudah proses penuangan maka diperlukan alat tuang. Alat tuang yang digunakan titik didihnya harus lebih tinggi dari aluminium yang dicairkan. Proses penuangan dilakukan dengan suhu tuang yaitu $700^{\circ} \mathrm{C}$.

\section{Proses peleburan alumunium}

1. Siapkan alat dan bahan untuk peleburan aluminium

2. Pasangkan termokopel pada titik-titik yang sudah ditentukan

3. Catat temperatur awal saat peleburan aluminium

4. Masukkan bahan bakar cangkang karet pada ruang bakar setinggi penyangga dan mulai proses pembakaran briket.

5. Masukkan aluminium secukupnya.

6. Tutup dapur krusibel.

7. Tambahkan bahan bakar secara terus menerus, jika bahan bakar mulai berkurang.

8. Setelah aluminium mulai mencair ukur temperaturnya secara berkala hingga mencapai suhu $700^{\circ} \mathrm{C}$.

9. Catat semua temperatur pada titik-titik yang telah ditentukan sebagai temperatur ahir peleburan dan catat waktu peleburan.

10. Tuang aluminium dengan menggunakan alat tuang pada cetakan logam.

11. Padamkan bara api.

12. Bersihkan tungku dan dinginkan hingga mencapai temperatur ruangan.

\section{Prosedur pengujian uji fatigue}

1. Pasang benda uji pada collet holder dan eratkan yang kuat.

2. Pasang cover transfaran dengan benar.

3. Hubungkan kabel jala listrik ke sumber daya.

4. Buka atau putar ke kanan tombol panik.
5. Kendorkan roda beban (berlawanan arah jarum jam, jangan sampai lepas) atau tanpa beban.

6. Atur tampilan forcemeter menjadi nol, dengan memutar potensio di sisi kanan panel.

7. Berikan beban pada benda uji dengan memutar roda beban searah jarum jam.

8. Reset countrmeter, tekan tombol reset di panel.

9. Tekan tombol Run-Stop untuk mengaktifkan motor speed control.

10. Tekan tombol Start pada speed control, tingkatkan frekwensi secara bertahap sampai putaran tertentu (perhatikan tachometer).

11. Amati forcemeter dan counter meter untuk keperluan data.

12. Mesin akan berhenti otomatis jika benda uji putus atau patah.

13. Menghentikan operasi sebelum patah, turunkan frekwensi dan tekan tombol Dtop pada speed control.

14. Tekan tombol Stop pada Run-Stop atau tekan tombol panik.

15. Lepaskan hubungan kabel jala listrik ke sumber daya, Dan Keluarkan patahan benda uji dari ruang mesin uji fatigue.

\section{Hasil dan Pembahasan}

\section{Pemberian kode benda uji}

Tabel 2. hasil pengujian tarik

\begin{tabular}{cccc}
\hline Spesimen & $\begin{array}{c}\text { Ultimate } \\
\text { Stress }\end{array}$ & $\begin{array}{c}\text { Yield } \\
\text { Strength }\end{array}$ & $\begin{array}{c}\text { Elasticity } \\
\text { Modulus }\end{array}$ \\
\hline \multirow{2}{*}{1} & 175.690 & 175.690 & 67.104 \\
& $\mathrm{Mpa}$ & $\mathrm{Mpa}$ & $\mathrm{Gpa}$ \\
\hline \multirow{2}{*}{2} & 174.665 & 157.457 & 67.517 \\
& $\mathrm{Mpa}$ & $\mathrm{Mpa}$ & $\mathrm{Gpa}$ \\
\hline Nila rata- & 175.177 & 166.573 & 67.310 \\
rata & $\mathrm{Mpa}$ & $\mathrm{Mpa}$ & $\mathrm{Gpa}$ \\
\hline
\end{tabular}

Dari data pengujian tarik di atas,dapat diketahui nilai dari Ultimate Stress, Yield Strength, dan Elasticity Modulus dari spesimen 1 (satu) dan 2 (dua), dan selanjutnya pembebanan pengujian fatigue di ambil dari nilai dari yield strength. 
Perhitungan beban yang di berikan pada uji fatigue

Beban yang diberikan pada pengujian di tentukan berdasarkan yield strength aluminium scrap hasil remelting sepatu rem bekas. Dari data data spesifikasi alumunium scrap di ketahui nilai yield strength adalah 167Mpa. Pengujian di lakukan sebanyak 9 (sembilan) kali dengan 3 (tiga) tegangan yang berbeda .Variasi tegangan yang di berikan adalah $40 \%, 50 \%$, dan $60 \%$ dari nilai yield strength.

Untuk menentukan beban yang di gunakan dalam pengujian, dilakukan 1 (satu) contoh perhitungan yang akan digunakan. Dari data spesifikasi aluminium scrap hasil remelting sepatu rem bekas di ketahui bahwa memiliki nilai yield strength 167 Mpa.

Data-data yang diketahui adalah sebagai berikut:

$$
\begin{aligned}
& \mathrm{L}=180 \mathrm{~mm} \\
& \mathrm{~d}=7 \mathrm{~mm} \\
& \sigma=167 \mathrm{Mpa}
\end{aligned}
$$

Beban pada pengujian $60 \%$ dari yield strength

$\sigma=\frac{W L / 2}{\pi / 32 d^{3}} \mathrm{~kg} / \mathrm{cm}^{2}$

$167 \mathrm{MPa} \times 60 \%=\frac{\frac{w .180 \mathrm{~mm}}{2}}{\frac{2}{32 .(7 \mathrm{~mm})}} \mathrm{kg} / \mathrm{cm}^{2}$

$$
\begin{gathered}
\frac{w .180 \mathrm{~mm}}{2}=(167 \mathrm{MPa} \times 60 \%) \\
{\left[\frac{\pi}{32}(7 \mathrm{~mm})^{3}\right]_{\frac{w .180 \mathrm{~mm}}{2}}=}
\end{gathered}
$$

$(100,2 M P a \times 33,656)$

$$
\begin{aligned}
\frac{w .180 \mathrm{~mm}}{2}=3.372,3 \mathrm{~N} / \mathrm{mm} \\
\\
w .180 \mathrm{~mm}=3.372,3 \times \\
2 \mathrm{~N} / \mathrm{mm} \\
\mathrm{W}=\frac{6.744,6}{180} \mathrm{~N} \\
\mathrm{~W}=37,47 \mathrm{~N} \\
\mathrm{~W}=3,81 \mathrm{~kg}
\end{aligned}
$$

Setelah dilakukan perhitungan, kemudian dengan cara yang sama hasil perhitungan untuk tegangan pada pengujian $40 \%$, dan $50 \%$ dari yield strength dan di masukan ke dalam tabel berikut:
Tabel 3. Data beban yang di berikan pada pengujian

\begin{tabular}{|c|c|c|c|c|}
\hline $100,2 \mathrm{MPa}$ & $3,81 \mathrm{Kg}$ & 1500 & 24.559 & $16: 22$ \\
\hline $100,2 \mathrm{MPa}$ & $3,81 \mathrm{Kg}$ & 1500 & 37.077 & $24: 42$ \\
\hline $100,2 \mathrm{MPa}$ & $3,81 \mathrm{Kg}$ & 1500 & 20.628 & $13: 45$ \\
\hline Nilai & Rata-rata & & 27.421 & $18: 16$ \\
\hline
\end{tabular}

\begin{tabular}{cccc}
\hline $\begin{array}{c}\text { Yield } \\
\text { Strength }\end{array}$ & $\begin{array}{c}\text { Variasi } \\
\text { beban } \\
\text { uji } \\
\text { fatigue } \\
(\%)\end{array}$ & $\begin{array}{c}\sigma \\
(\mathrm{Mpa})\end{array}$ & $\begin{array}{c}\mathrm{W} \\
(\mathrm{kg})\end{array}$ \\
\hline $167 \mathrm{Mpa}$ & $40 \%$ & $66,8 \mathrm{Mpa}$ & $2,5 \mathrm{~kg}$ \\
\hline $167 \mathrm{Mpa}$ & $50 \%$ & $83,5 \mathrm{Mpa}$ & $3,18 \mathrm{~kg}$ \\
\hline $167 \mathrm{Mpa}$ & $60 \%$ & $100,2 \mathrm{Mpa}$ & $3,81 \mathrm{~kg}$
\end{tabular}

\section{Hasil pengujian Fatigue}

Setelah dilakukan perhitungan untuk menentukan beban pengujian kelelahan pada aluminium scrap hasil remelting sepatu rem bekas. dengan menggunakan mesin uji fatigue rotary bending di dapat hasil yang di tunjukan pada tabel berikut.

Tabel 4. Data tegangan 60\% dari Yield Strength

\begin{tabular}{|c|c|c|c|c|}
\hline $\begin{array}{c}\sigma_{y} \mathrm{MPa} \\
50 \%\end{array}$ & Beban & Rpm & putaran & Waktu \\
\hline $83,5 \mathrm{MPa}$ & $3,18 \mathrm{Kg}$ & 1500 & 47.205 & $31: 28$ \\
\hline $83,5 \mathrm{MPa}$ & $3,18 \mathrm{Kg}$ & 1500 & 57.087 & $38: 30$ \\
\hline $83,5 \mathrm{MPa}$ & $3,18 \mathrm{Kg}$ & 1500 & 50.684 & $33: 47$ \\
\hline & 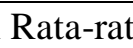 & & 51.659 & $34: 35$ \\
\hline
\end{tabular}
$\sigma_{y} \mathrm{MPa}$ Beban Rpm putaran Waktu

Dari data tabel di atas dapat di lihat bahwa nilai patah materialnya tidak sama, untuk pembebanan $60 \%$ bisa di lihat yang paling baik nilai lelahnya yaitu di kolom nomor 2 (dua). dari satu pembebanan terdapat 3(tiga) hasil nilai, nilai tersebut di rata-ratakan untuk pembuatan kurva $\mathrm{S}-\mathrm{N}$.

Tabel 5. Data tegangan $50 \%$ dari Yield Strength 
Dari data tabel dapat dilihat bahwa nilai putus materialnya tidak sama, untuk pembebanan $50 \%$ ini bisa di lihat yang paling baik nilai lelah nya yaitu di kolom nomor 2 (dua). dari satu pembebanan terdapat 3(tiga) hasil nilai, nilai tersebut di rata-ratakan untuk pembuatan kurva $\mathrm{S}-\mathrm{N}$.

Tabel 6. Data tegangan $40 \%$ dari Yield strength

\begin{tabular}{|c|c|c|c|c|}
\hline $\begin{array}{c}\sigma_{y} \mathrm{MPa} \\
40 \%\end{array}$ & Beban & Rpm & putaran & Waktu \\
\hline $\begin{array}{l}66,8 \\
\mathrm{MPa} \\
\end{array}$ & $2,5 \mathrm{Kg}$ & 1500 & 123.607 & $01: 22: 24$ \\
\hline $\begin{array}{l}66,8 \\
\mathrm{MPa}\end{array}$ & $2,5 \mathrm{Kg}$ & 1500 & 96.197 & 01:04:08 \\
\hline $\begin{array}{l}66,8 \\
\mathrm{MPa}\end{array}$ & $2,5 \mathrm{Kg}$ & 1500 & 100.987 & 01:07:19 \\
\hline Nil & Rata-r & & 106.930 & 01:11:17 \\
\hline
\end{tabular}

Dari data tabel dapat dilihat bahwa nilai patah materialnya tidak sama, untuk pembebanan $40 \%$ ini bisa di lihat yang paling baik nilai lelah nya yaitu di kolom nomor 1 (satu). dari satu pembebanan terdapat 3 (tiga) hasil nilai, nilai tersebut di rata-ratakan untuk pembuatan kurva S-N.

Dari pengujian yang telah di lakukan dapat di lihat hasil pengujian bahwa waktu yang didapat sampai spesimen mengalami kelelahan (patah) berbeda-beda itu dikarenakan pengaruh tegangan yang di berikan pada masingmasing spesimen, dari perbedaan tegangan itulah didapat beban yang di berikan berbeda pula untuk setiap spesimen, jadi dapat di lihat bahwa pemberian tegangan yang besar akan mengakibatkan spesimen mengalami kegagalan dalam waktu yang lebih cepat, begitupun sebaliknya jika tegangan yang di berikan kecil maka waktu spesimen untuk mengalami kegagalan lebih lama.

\section{Grafik kurva S-N}

Setelah didapat hasil pengujian kelelahan (fatigue) yang dilakukan terhadap benda uji didapatkan data dalam bentuk kurva S-N yang terlihat pada grafik berikut:

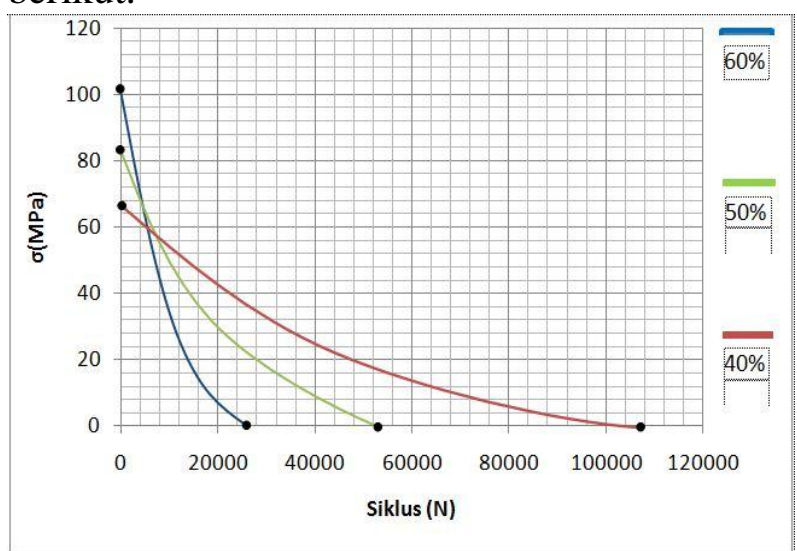

Gambar 6. Grafik nilai fatigue

Dari kurva S-N penggujian aluminium scrap hasil remelting sepatu rem bekas dapat dilihat bahwa dari hasil pengujian fatigue pada pembebanan $60 \%$ dengan tegangan 100,2 $\mathrm{MPa}$ dan beban yang di berikan $3,81 \mathrm{~kg}$ dapat di ketahui nilai patah material pada siklus 27.421. Kemudian pada pembebanan $50 \%$ dengan tegangan $83,5 \mathrm{MPa}$ dan beban yang di berikan $3,18 \mathrm{~kg}$ dapat di ketahui nilai patah material pada siklus 51.659. Lalu pada pengujian yang berikutnya dengan pembebanan $40 \%$ serta tegangan yang di berikan $66,8 \mathrm{MPa}$ dan beban yang di berikan $2,5 \mathrm{~kg}$ di ketahui nilai patah materialnya pada siklus 106.930. Maka dapat di simpulkan bahwa perbandingan antara siklus dengan tegangan adalah perbandingan terbalik, yaitu semakin kecil tegangan semakin besar siklus dan waktu yang di dapat, begitupun sebaliknya semakin besar tegangan maka akan semakin kecil siklus dan waktu yang di dapat.

\section{Grafik waktu putus}

Variasi setiap pembenanan memiliki waktu yang berbeda-beda, waktu tersebut berkaitan dengan pembeban yang di berikan terhadap spesimen yang telah di uji fatigue. Berikut ini adalah garfik dari rata-rata waktu pembebanan yang diperoleh setelah pengujian yang dilakukan. 


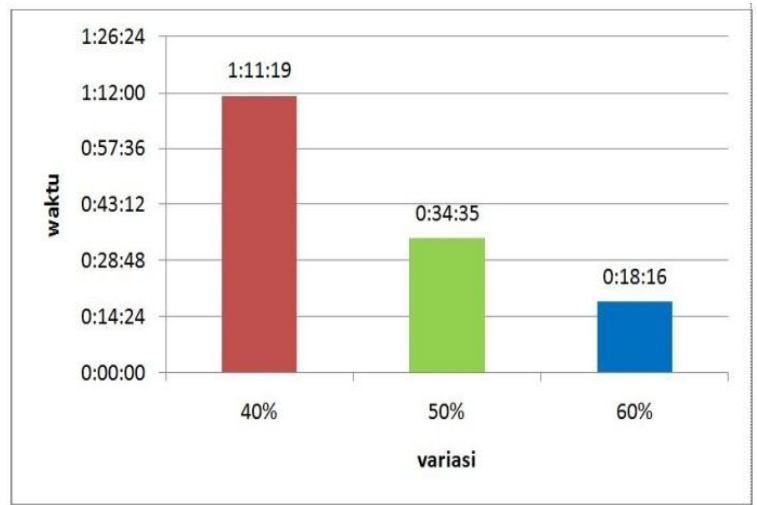

Gambar 7. Grafik rata - rata waktu pembebanan

Dari grafik bisa kita ketahui bahwa pembebanan $40 \%$ rata-rata spesimen putus dalam kurun waktu mencapai 01:11:19, dan pada pembebanan $50 \%$ rata-rata waktu spesimen putus mendapatkan waktu mencapai 00:34:35, kemudian pada pembebanan $60 \%$ rata-rata spesimen mengalami putus pada waktu 00:18:16. Jadi disini bisa di lihat perbedaan masingmasing variasi mengalami waktu putus yang berbeda, jadi semakin besar beban yang di berikan terhadap spesimen maka akan semakin cepat waktu kelelahan yang didapat, Begitupun sebaliknya semakin kecil beban yang di berikan maka semakin lama waktu yang didapat.

\section{Analisa patahan}

Analisa patahan dilakukan untuk mengetahui bagaimana terjadinya awal retakan hingga mencapai patahnya material tersebut terhadap variasi beban yang berbeda. analisa ini juga bertujuan untuk mengetahui perbedaan bentuk permukaan yang patah akibat dari pengujian fatigue. Berikut adalah perbedaan patahan dengan variasi beban yang berbeda. Permukaan patahan pada beban $40 \%$.

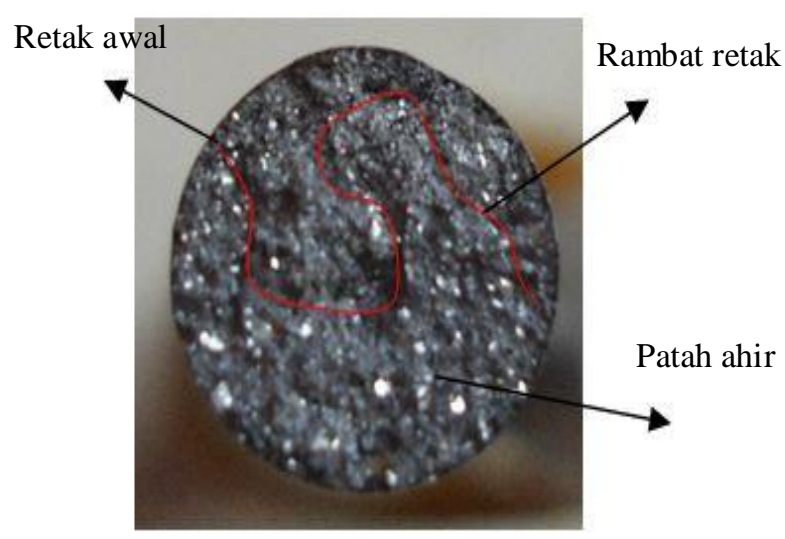

Gambar 8. Permukaan patahan dengan beban 66,8 Mpa

Dari gambar di atas dapat di lihat bahwa patahan yang terjadi akibat pembebanan $66,8 \mathrm{MPa}$ mengalami satu retakan dan merambat ke bagian lain sehingga material tersebut tidak mampu lagi menahan beban yang di berikan dan terjadilah perpatahan.

\section{A. Permukaan patahan pada beban $50 \%$}

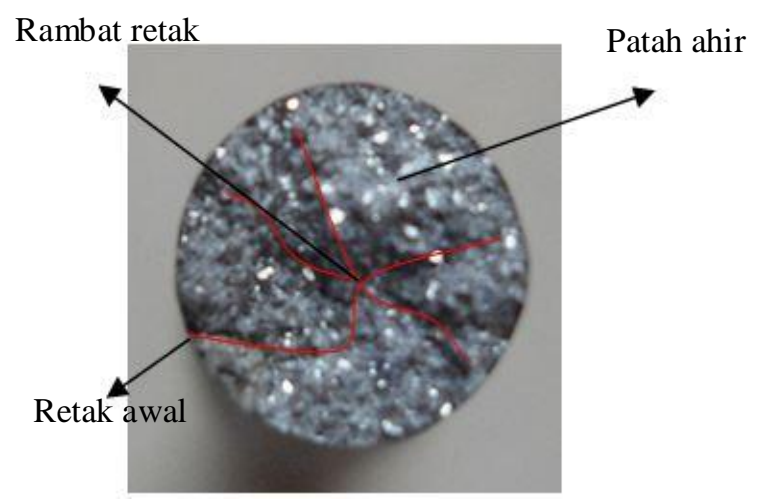

Gambar 9. Permukaan patahan dengan beban 83,5 Mpa

Pada pengujian dengan pembebanan 83,5 $\mathrm{MPa}$ ini bisa di lihat bahwa permukaan patahan memiliki satu awal retak dan memiliki rambat retakan lebih banyak di bandingkan dengan pengujian dengan pembebanan $66,8 \mathrm{MPa}$ yang hanya memiliki satu awal retak dan satu rambat retakan, itu terjadi karena pembebanan yang di berikan lebih berat dari pada beban sebelumnya. 


\section{B. Permukaan patahan pada beban $60 \%$}

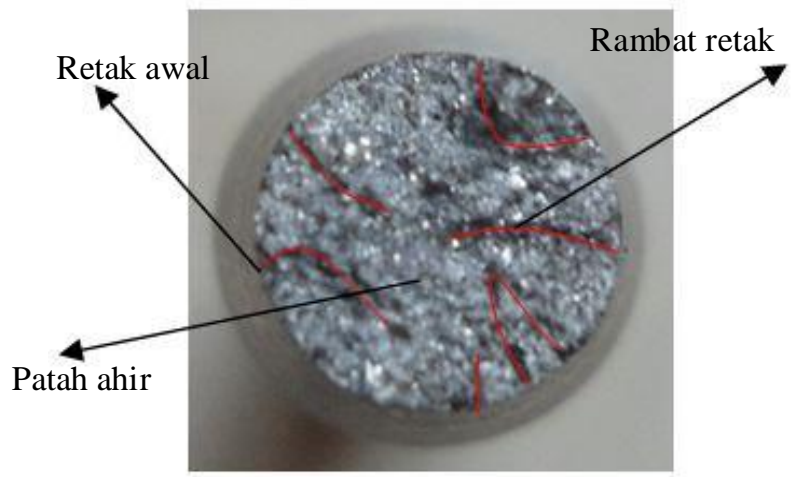

Gambar 10. Permukaan patahan dengan beban 100,2 $\mathrm{MPa}$

Pengamatan pada permukaan patahan dengan beban $100,2 \mathrm{MPa}$ ini memiliki awal retak dan rambat retak yang lebih banyak di bandingkan dengan kedua spesimen yang di beri pembebanan dibawahnya. Karena awal retak dan rambat retaknya lebih banyak maka spesimen tersebut mudah patah dengan jangka waktu yang lebih cepat.

Dari pembahasan analisa tersebut di ketahui perbedaan dari setiap patahan ternyata memiliki karakteristik masingmasing. Semakin besar beban yang di berikan kepada spesimen maka awal retak dan rambat retak semakin banyak sehingga spesimen tersebut mudah patah dengan waktu yang cepat. Begitupun sebaliknya semakin kecil beban yang di berikan terhadap spesimen maka awal retak dan rambat retaknya pun semakin sedikit, dan menjadikan waktu patah spesimen semakin lama.

Keterkaitan antara pembebanan dan bentuk permukaan patahan ini terlihat jelas dari hasil pengujian dan pengamatan yang telah dilakukan. Pengujiann tersebut menggambarkan keadaan patahan spesimen yang berbeda dari variasi beban yang berbeda.

\section{Kesimpulan}

Dari hasil pengujian fatigue dan analisa patahan yang telah di lakukan dapat disimpulkan bahwa aluminium scrap hasil remelting sepatu rem bekas sebagai berikut:
1. Dari hasil pengujian fatigue pada pembebanan $60 \%$ tegangan $100,2 \mathrm{MPa}$ dan beban $3,81 \mathrm{~kg}$ mendapatkan siklus 27.421 kurun waktu 00:18:16. Pada pembebanan $50 \%$ tegangan $83,5 \mathrm{MPa}$ dan beban $3,18 \mathrm{~kg}$ mendapatkan siklus 51.659 kurun waktu 00:34:35. Lalu pada pembebanan $40 \%$ tegangan $66,8 \mathrm{MPa}$ dan beban $2,5 \mathrm{~kg}$ mendapatkan siklus 106.930 dalam waktu 01:11:17. Maka dapat di simpulkan bahwa perbandingan antara siklus dan waktu dengan tegangan adalah perbandingan terbalik, yaitu semakin kecil tegangan semakin besar siklus dan waktu yang di dapat, begitupun sebaliknya semakin besar tegangan maka akan semakin kecil siklus dan waktu yang di dapat.

2. Bentuk permukaan patahan yang terjadi akibat pengujian fatigue dapat di ketahui bahwa patahan pembebanan $40 \%$ dengan tegangan $66,8 \mathrm{MPa}$ mengalami satu retakan dan merambat ke bagian lain. kemudian pada pembebanan 50\% dengan tegangan $83,5 \mathrm{MPa}$ ini bisa di lihat bahwa permukaan patahan memiliki satu awal retak dan memiliki rambat retakan lebih banyak. Dan pada pembebanan $60 \%$ dengan tegangan $100,2 \mathrm{MPa}$ memiliki awal retak dan rambat retak yang lebih banyak di bandingkan dengan spesimen sebelumnya. Dari analisa permukaan patahan tersebut dapat di simpulkan bahwa perbedaan dari setiap patahan ternyata memiliki karakteristik masingmasing

\section{Referensi}

[1] Anshari Hafis Syarifudin. 2010. Karakteristik Laju Perambatan Retak Fatik Bahan Komposit Berpenguat Serat Kenaf Dengan Matrik Polyeste. Jurusan Teknik Mesin, Fakultas Teknik, Universitas Sebelas Maret Surakarta.

[2] Bayuseno Athanasius Priharyoto, dkk. 2011. ADC 12 Sebagai material 
sepatu rem menggunakan pengecoran high pressure die casting dengan variasi temperatur penuangan. Jurusan Teknik Mesin, Universitas Diponegoro.

[3] Budiyanto. 2008. Pengaruh Temperatur Penuangan Paduan ALSI (seri 4032) Terhadap Hasil Pengecoran. Fakultas Teknologi Industri. Istitut Teknologi Nasional Malang.

[4] Caing. 2009. Pengaruh Titanium. Fakultas Matematika dan Ilmu Pengetahuan Alam, Universitas INDONESIA.

[5] Kondi Maliwemu Erich Umbu, dkk. 2012. Karakteristik perambatan retak fatik aluminium scrap dengan variasi putaran centrifugal casting. Jurusan Teknik Mesin , Universitas Nusa Cendana.

[6] Nur Eva Azis. 2012. Analisis sifat fisis dan mekanis aluminium paduan $\mathrm{Al}-\mathrm{Si}-\mathrm{Cu}$ dengan menggunakan cetakan pasir. Jurusan Teknik Mesin, Universitas Muhammadiyah Surakarta.

[7] Nurhadi Muhammad, 2013. Analisa Kekuatan Fatik Aluminium Cor (Remelting) Dengan Tipe Rotary Bending. Fakultas Teknik, Universitas Lampung.

[8] Prawoto Bambang, dkk. 2016. Analisis Kekuatan Fatik Baja Karbon Rendah SC10 Dengan Tipe Rotary Bending. Teknik Mesin, Universitas Bandar Lampung

[9] Sugiarto Teguh, dkk. 2013. Analisis uji ketahan lelah baja karbon sedang AISI 1045 dengan heat treatment (quenching) dengan menggunakan alat rotary bending. Jurusan Teknik Mesin, Universitas Lampung.
[10] Supriyono, dkk. 2010. Analisa Kegagalan Poros PoMPa Air Laut Pada Unit PLTU. Teknik Mesin, Fakultas Teknologi Industri, Universitas Gunadarma.

[11] Surojo Eko, dkk. 2009. Pengaruh remelting terhadap struktur mikro dan kekerasan paduan cor Al - Si. Jurusan Teknik Mesin, Universitas Negeri Surakarta.

[12] Susilo iwan. 2016. Pengaruh Artificial Aging Pada Variasi Temperatur Tuang Terhadap Sifat Mekanis Hasil Pengecoran Piston Bekas. Jurusan Teknik Mesin, Universitas Muhammadiyah Metro.

[13] Tawaf nanang, dkk. 2014. Analisis fatigue failure suhu rendah struktur batang duralumin dengan mesin siklus bending. Jurusan Teknik Mesin, Universitas Brawijaya.

[14] Drihandono, S., \& Budiyanto, E. (2017). Pengaruh Temperatur Tuang, Temperatur Cetakan, dan Tekanan Pada Pengecoran Bertekanan (High Pressure Die Casting/HPDC) Terhadap Kekerasan dan Struktur Mikro Aluminium Paduan Silikon (Al-Si 7, 79\%). Turbo: Jurnal Program Studi Teknik Mesin, 5(1).

[15] Budianto, E., Choiron, M. A., \& Darmadi, D. B. (2016). Hardening Baja AISI 1045 Menggunakan Gel Aloe Vera Sebagai Media Pendingin. Rekayasa Mesin, 7(2), 5564.

[16] Nugroho, E., Budiyanto, E., Kurniawan, R., \& Sumosusilo, J. (2020). Uji ketahanan fatik aluminium hasil remelting piston bekas menggunakan metode pengecoran centrifugal casting. Turbo: Jurnal Program Studi Teknik Mesin, 8(2). 
[17] Budiyanto, E., Nugroho, E., \& Zainudin, A. (2018). Uji Ketahanan Fatik Aluminium Scrap Hasil Remelting Piston Bekas Menggunakan Alat Uji Fatik Tipe Rotary Bending. Turbo: Jurnal Program Studi Teknik Mesin, 7(1).

[18] Budiyanto, E., Asroni, A., \& Pramono, A. (2017). Pengaruh Temperatur Cetakan Dan Lama Pengempaan Terhadap Keteguhan Rekat Pada Kayu Lapis Sebagai Bahan Baku Pembuatan Drum Shell. Turbo: Jurnal Program Studi Teknik Mesin, 5(2). 